\title{
O OLHO DO ETNÓGRAFO ${ }^{1}$
}

\author{
Rapprocher l'œil de l'objet induit une autre façon de voir \\ [Aproximar o olho do objeto induz a uma outra maneira de ver] \\ Jean Jamin (1987: 85)
}

Etnologia e viagem são termos irmãos. O deslocamento no espaço e a experiência junto a culturas diferentes fornecem as balizas para a produção do conhecimento antropológico, mesmo para o antropólogo de gabinete, que compõe suas interpretações não apenas em função dos resultados trazidos por outros, mas, sobretudo, a partir dos rendimentos epistemológicos das viagens realizadas por terceiros. O trabalho de campo e a construção da etnografia, móveis do deslocamento espacial, alteram radicalmente as formas de ver-pensar o mundo daqueles que experimentam diretamente essa modalidade de trabalho, e também dos que a vivenciam de forma mediada, mas que nem por isso deixam de aprender (e se transformar) com ela.

Proponho aqui a retomada dos temas da viagem etnográfica e da formação do etnólogo a ela associada por uma via oblíqua: o exame de um texto do escritor e antropólogo Michel Leiris (1901-1990), escrito pouco antes de sua primeira viagem de campo à África, quando ele integra a Missão Etnográfica e Linguística Dacar-Djibouti (1931-1933), pesquisa extensiva que atravessa o Continente africano da costa atlântica ao Golfo de Adén, às portas do Mar Vermelho. Trata-se de um relato de viagem (ou sobre a viagem) antes de sua concretização.

Não é a primeira vez que L'œil de l'ethnographe (à propos de la Mission Dakar-Djibouti), publicado originalmente na revista Documents, em dezembro de 1930, merece a atenção da crítica, ainda que ele seja mais mencionado do que efetivamente analisado. Louis Yvert, responsável pela organização da bibliografia de Leiris, refere-se a ele como o "primeiro escrito etnográfico" do autor (Yvert, 1996: 2). Leiris não fala do texto como inaugurando sua produção etnográfica; nem por isso deixa de incluí-lo em seu dossiê de candidatura ao Centre National de la Recherche Scientifique (CNRS), em 1967, como parte da rubrica "ciências humanas" de sua produção, ao lado de outros artigos e resenhas que escrevera 
para Documents. ${ }^{2}$ Recupera-o, posteriormente, em Zébrage (Leiris, 1992a), coletânea organizada antes de seu falecimento, ainda que, segundo Jean Jamin - seu principal colaborador e leitor -, tenha hesitado em fazê-lo. Jamin alerta ainda para os mal-entendidos que cercaram o texto; afinal, menos do que uma "visão etnográfica", como supõe o título, o artigo apoia-se em recordações de infância, sendo mais importante para a obra autobiográfica futura do autor do que para a reflexão antropológica propriamente dita (Leiris, 1999: 264).

Por que então voltar a esse escrito de circunstância - trompeur [enganoso] nos termos de Jamin - analisando-o? A aposta primeira é que, observado no detalhe, ele se mostra valioso do ponto de vista das reflexões que lança sobre a viagem em geral e sobre a viagem etnográfica em particular. Sua originalidade decorre precisamente da posição de espera em que se encontra o autor-narrador (que viajará pouco depois). Momento intervalar por excelência, e marcado por expectativas em relação ao que estar por vir, a espera equilibra imobilidade e movimento, passado e futuro, sinteticamente condensados no exato presente que antecede o ato (no caso, a partida).

O texto fornece também um mapa condensado das ideias em circulação sobre a África nos anos 1920 e das referências intelectuais de Michel Leiris em etapa de formação do etnólogo, outro de seus interesses. Tendo "rompido oficialmente" com o surrealismo em fevereiro de 1929, como afirma em seu diário (Leiris, 1992b: 159), ${ }^{3}$ ele incorpora-se à Documents, revista que vem à luz nesse mesmo ano, sob direção de Georges Bataille (1897-1962). ${ }^{4}$ Se a "etnografia" - que figura no subtítulo da publicação - possui maior relação com uma postura de descentramento do que com método ou trabalho científico (Jamin, 1999: 266), parece difícil desconhecer sua importância como espaço de encontro e circulação de saberes, científicos e artísticos, e que afetou os que dela participaram. É aí que Leiris recebe o convite de Marcel Griaule ${ }^{5}$ para integrar a missão africana, que faz dele um etnólogo; é também no seu interior que exercita uma forma de olhar e uma modalidade de escrita, a partir do interesse pelas sociedades distantes, e da atenção concedida às imagens e aos objetos. ${ }^{6}$

"O olho do etnólogo" traz as marcas dessa experiência formadora, híbrida e ímpar que Documents representa. Fiel ao espírito da revista, o texto dificilmente poderia ser classificado como "etnológico", ainda que esteja informado pela experiência etnográfica que se anuncia. Mas não se trata aqui de classificá-lo como "científico" ou "literário", mas de observar, pela aproximação do foco da leitura, o modo como essas faces se imbricam no interior dessa composição específica (como, aliás, em parte substantiva da produção do autor).

Suspeito que esse exercício possa contribuir ainda para recuperarmos as potencialidades do projeto da Documents - ativismos e modismos à parte para a reflexão atual, sobretudo no que diz respeito à atenção aí conferida aos objetos, rompendo com todo tipo de hierarquia entre a produção ocidental e as demais. E tal recuperação se inicia na montagem mesma da leitura aqui 
proposta. Trata-se de mimetizar deliberadamente o treino rotineiro dos partícipes da revista, aproximando o olho do objeto, apoiada na convicção de que tal movimento conduz efetivamente a outra maneira de ver.

\section{QUADRO GERAL}

Datado de "Paris, 7 de novembro de 1930", "O olho do etnógrafo (a propósito da Missão Dacar-Djibouti)", encontra-se no sétimo número da publicação, em seu segundo ano. Uma fotografia da "Expedição Seabrook" ao então Sudão francês (mostrando um sacrifício animal) e uma nota explicativa assinada por Georges Henri-Rivière abrem o texto:

A grande imprensa anunciou a partida próxima - no começo de 1931 - da missão Dakar-Djibouti que se propõe, em dois anos aproximadamente, a atravessar a África do Oceano Atlântico ao Oceano Índico [...]. Esta expedição, organizada pelo Institut d'Ethnologie e pelo Museum d'Histoire Naturelle, patrocinada e subvencionada por diversos ministérios e governos das colônias ao mesmo tempo que pelos mais importantes organismos científicos (entre outros o Institut de France e a Université de Paris), tem por principais objetivos: a formação de coleções para o Museum d'Histoire Naturelle e o Musée du Trocadéro, o estudo de numerosos povos e costumes que estão em vias de desaparição [...], a realização de filmes documentários e o registro em discos de línguas e cantos, a criação entre os funcionários coloniais e os organismos científicos da metrópole, de relações indispensáveis ao desenvolvimento das ciências naturais e sociológicas (Rivière, 1930; 405-406). ${ }^{7}$

Mais adiante, Rivière arrola alguns de seus principais integrantes, todos colaboradores de Documents: Marcel Griaule, "à la tête" da missão; André Schaeffner, ${ }^{8}$ encarregado do Service d'Organologie Musicale [Serviço de Organologia Musical] do Musée d'Ethnographie du Trocadéro [Museu de Etnografia do Trocadero] e Michel Leiris, na função de secretário arquivista. E finaliza: "A direção de Documents julgou conveniente pedir a este último algumas impressões sobre o empreendimento do qual participará, o primeiro na França de tal envergadura, no domínio da etnografia e da linguística" (Rivière, 1930: 406).

As palavras de Rivière contêm pelo menos dois pontos dignos de nota para os objetivos deste texto. Primeiro, o artigo de Leiris nasce de uma encomenda da "direção de Documents"; segundo, parece impossível dissociar a revista, a missão científica e os museus, partes de uma mesma rede da qual fazem parte homens de ciência e artistas, envolvidos em uma série de projetos comuns. A imbricação dos circuitos artísticos e científicos na França dos anos 1920 e 1930 confere feições específicas à antropologia aí praticada, que vai ocupar lugar de destaque na cena cultural mais ampla, aspecto também assinalado pela nota de Rivière, quando diz ter sido a missão etnográfica "anunciada pela grande imprensa". Longe de querer recuperar aqui esse contexto, já tão visitado pelos comentadores - que envolve a reorganização do Musée d'Ethnographie du 
Trocadéro, a criação de Documents, a preparação da Missão Dacar-Djibouti, a publicação de seus primeiros resultados na luxuosa Minotaure etc. ${ }^{9}$ - trata-se somente de sublinhar que o texto de Leiris é expressão eloquente dessa paisagem particular, traduzindo, a seu modo, a intensa comunicação entre vanguardas artísticas e científicas na Paris do entre-guerras.

Assim que não causa estranheza o fato de o texto encomendado a ele não ser exatamente sobre a Missão Dacar-Djibouti, como leva a crer o seu subtítulo e as linhas iniciais de Rivière. O escrito se afina com perfeição ao espírito da Documents, pelo seu caráter inusitado; pela forma fragmentada (uma colagem de recordações de infância, leituras e imagens); pela relação forte entre o texto e as ilustrações que o acompanham, e, ainda, pelo distanciamento crítico que o autor manifesta em relação ao contexto europeu de seu tempo.

A ideia da revista parece ter sido de Georges Henri-Rivière, ele mesmo um perfil múltiplo - etnógrafo, pianista e museólogo - que Leiris conhecera em 1921 no apartamento de primos distantes, que recebiam personalidades da cena artística e intelectual regularmente em sua casa. Nesse contexto, encontra Maurice Ravel, Erik Satie e "um jovem alto de silhueta magra e longilínea, nascido em 1897, então pianista e amante do jazz, Georges-Henri Rivière” (Armel, 1997: 148).

Rivière tem papel decisivo na carreira etnográfica de Leiris:

[...] foi por meio de Rivière que conheci Rivet e foi através de Rivière que recebi durante algum tempo uma ajuda mensal de D. David-Weil [colecionador e mecenas do Trocadéro] de modo a dobrar meus ganhos que eram bem magros. Fui conquistado imediatamente por Rivière: com seu ar desenvolto e seus olhos de animal, extraordinariamente inteligentes, ele me fazia pensar à Dolmancé, o organizador do jogo em La philosophie dans le boudoir [...] (Leiris, 1992: 30)..$^{10}$

Rivière, que trocaria o piano pelos projetos museológicos - primeiro no Trocadéro, depois no Musée des Arts et Traditions Populaires [Museu de Artes e Tradições Populares] - funciona como elemento aglutinador de diferentes universos e personagens. Em 1928, quando organiza com Paul Rivet a exposição Les arts anciens de l'Amérique, no pavilhão de Marsan do Musée des Arts Décoratifs [Museu de Artes Decorativas], convida o americanista Alfred Métraux (1902-1963) para dela participar; este, por sua vez, sugere o nome de seu antigo colega da École de Chartes, Georges Bataille, para escrever um artigo sobre os astecas (Bataille, 1970). ${ }^{11}$ Tomam parte também da montagem dessa exposição, Schaeffner e Leiris, que formariam com Bataille e Rivière o núcleo da Documents. É graças à Rivière que Leiris é indicado a fazer parte da Dacar-Dijibouti, ${ }^{12}$ o que reafirma a sua importância na recondução dos rumos de sua carreira.

A experiência em Documents representa um elemento fundamental para o treinamento do olhar de Leiris. Já familiarizado com o mundo das artes plásticas em função dos círculos surrealistas que frequentara e, mais especificamente, dos ateliês de André Masson e de Joan Miró, que fizeram da rua Blomet, entre 
1922 e 1928, um espaço de intensa sociabilidade e aprendizados, ${ }^{13}$ a revista permite que ele teste uma nova modalidade de observação, descrição e interpretação de objetos e "documentos" os mais variados, atento às suas formas, usos e sentidos. Em consonância com a "perspectiva visual" da revista, e com a reflexão museológica levada a cabo pelo Musée du Trocadéro, que Documents acompanha, ${ }^{14}$ Leiris realiza aí uma educação do olhar diante de imagens de procedências diversas: obras dos então jovens Miró e Picasso, e do desconhecido Antoine Caron; figuras "microcósmicas dos séculos XIV e XV"; representações do corpo no desenho científico, fotografias de Seabrook, o cinema de Buster Keaton; o arranha-céu, o cuspe (tomado como símbolo do "informe")... Portanto, não parece exagerado afirmar que a "antropologia das formas" exercitada por Bataille nas páginas da revista (Didi-Huberman, 2003) tem em Leiris um fiel seguidor e cúmplice.

A arte negra (africana e norte-americana), a magia, a religião vodu e o ocultismo, ao lado de algumas leituras (de Mythes of the origin of fire, de James Georges Frazer, resenhado no número 5, 1930) são outros indícios da preparação particular pela qual passa o futuro etnógrafo na redação de Documents. Tal iniciação se beneficia ainda de outros aprendizados: as leituras de Lévy-Bruhl e a amizade com Bataille, que o levam aos cursos de Marcel Mauss entre 1929 e 1930 (aos quais retorna, de maneira mais assídua, na volta do périplo africano); também os escritos de Durkheim, Freud e Rousseau, que empreende nessa época. E em 12 de maio de 1929, um registro em seu diário permite flagrar marcas desse contato primeiro com a antropologia: certas interpretações "tendenciosas" dos sociólogos e psicólogos se explicam, diz ele, em função da ausência de "observações diretas" das sociedades, o que os leva a inventar "robinsonnades" sobre a vida dos primitivos (Leiris, 1992b: 157).

As seis imagens que acompanham L'œil de l'ethnographe - três de Seabrook, duas de Griaule e uma de Hugo A. Bernatzik ${ }^{15}$ - todas realizadas durante viagens à África, mostram figuras humanas, rituais e os próprios antropólogos em campo, como a que fecha o texto. Nesta última, os integrantes da missão Griaule de 1928, emoldurados por ampla paisagem, caminham em direção desconhecida. Partem, literalmente, como fará Leiris em pouco tempo, quando irá integrar um grupo similar ao fixado na fotografia. Nesse sentido, as imagens, menos do que ilustrações do texto, que se lança pelo relato de outras histórias e de recordações de infância, complementa-o, conferindo a ele tom francamente etnográfico.

William Seabrook (1884-1945) - viajante, jornalista e fotógrafo norte-americano - é o autor de três das fotografias que acompanham o artigo, na seguinte ordem: a que mostra o sacrifício de um cabrito pelos habbé do Sudão francês, ${ }^{16}$ na abertura; a de uma dança de máscaras, na Costa do Marfim, e a última, na qual figuram crianças habbé recém-circuncidadas. Seabrook é, também, o autor de Magic island (1929), relato de viagem ao Haiti, durante a qual descreve cultos vodus, obra imediatamente traduzida para o francês e comentada por Leiris no 
sexto número de Documents (1929). A leitura de Leiris destaca: a presença viva da magia em regiões do mundo ainda não submetidas a uma "civilização puramente utilitária"; o caráter da descrição de Seabrook - que "compreende" sem se deixar levar por avaliações preconceituosas - e o tom "concreto e vivo" de seu estilo. Observações reveladoras das preocupações de Leiris nesse momento: tentar compreender as outras sociedades descartando visões preconcebidas (no que seria auxiliado pela antropologia) e conferir à escrita um tom "concreto e vivo" (por ele mesmo ensaiado nos textos que escreve para Documents).

Seabrook volta a receber a atenção de Leiris em Le "caput mortuum" ou la femme de l'alchimiste, editado no número 8 (1930). O artigo, escrito mais ao menos na mesma época que L'œil de l'ethnographe, pode ser lido como uma versão modificada deste. Do primeiro, como dito, fazem parte três fotos de Seabrook, que funcionam como complemento (e contraponto) do texto escrito. No segundo, o fotógrafo é o responsável pelas três únicas imagens do artigo: fotografias de uma mulher vestida com máscara de couro, por ele concebida e executada sob sua orientação. E são as imagens, nesse caso, que disparam a escrita, dedicada a refletir sobre a máscara e os efeitos, eróticos e místicos, do ato de cobrir (ou negar) o rosto.

Se texto e imagem funcionam, agora, como partes inseparáveis uma da outra (como a máscara que se cola ao rosto, espécie de segunda pele), Seabrook converte-se em um duplo de Leiris:

Seabrook e eu amamos os negros; somos, ambos, apaixonados pelo ocultismo (eu, como curioso; ele como praticante); mas somos, todos os dois, mais do que céticos em relação aos interesses da civilização ocidental moderna, e plenamente convencidos de que uma das únicas tarefas válidas a que um homem pode se propor é a abolição, por qualquer que seja o meio (misticismo, loucura, aventura, poesia, erotismo...), dessa insuportável dualidade estabelecida, graças ao zelo de nossa moral corrente, entre corpo e alma, matéria e espírito. Não foi preciso mais do que isso para que tenhamos nos sentido imediatamente amigos e para que - hoje que tenho a perspectiva de deixar a Europa em pouco tempo e de ficar afastado por um bom tempo - eu me dê conta que Seabrook será um dos poucos homens que me farão falta durante essa ausência e, dentre estes, um dos quais eu mais sentirei saudades (Leiris, 1992a: 36).

Nesse segundo texto, Leiris vale-se também de pedaços de outras histórias para compor a sua, retomando o procedimento empregado em L'œil de l'ethnographe. Transcreve, neste caso, uma historieta ouvida por Seabrook durante viagem à Arábia, em 1927. A história fala de um jovem asceta que, após sua formação mística, encontra-se finalmente preparado para ver a face de Deus. Temeroso, e tentando, em vão, escapar ao desafio que lhe fora lançado por um velho monge, finalmente o enfrenta. Interrogado pelo monge sobre o ocorrido, diz, aterrorizado, ter visto a face de Deus, mas o que mostrava ela? O seu próprio rosto.

O conto reedita, com variações, a história africana, retirada de L'âme nègre (1922), do africanista Maurice Delafosse, com a qual Leiris encerra L'œil 
de l'ethnographe: um homem, Abarnakat, viaja com seus companheiros. Tem um lenço vermelho amarrado no pescoço, uma manta vermelha e um asno. Para dormir, amarra o asno aos seus pés e cobre-se com a manta. Uma noite, um de seus companheiros se levanta, tira o lenço do pescoço de Abarkanat e amarra no seu próprio; retira também a manta, desamarra o asno e deita-se sob uma árvore, com o asno amarrado aos pés, o lenço vermelho no pescoço e a manta estendida sobre o corpo. Quando Abarkanat acorda e vê o amigo, diz: "essa pessoa é Abarkanat... e eu, quem sou?". E se levanta chorando...

\section{PRIMEIRO SEGMENTO}

L'œil de l'ethnographe tem início com recordações de infância: em 11 de maio de 1912, aos onze anos, Leiris vai ao teatro com os pais e assiste à apresentação de Impressions d'Afrique, de Raymond Roussel (1877-1933), peça construída a partir de um romance de mesmo nome, publicado três anos antes, e concebido a partir de relatos de viagens, sem que o escritor tenha jamais ido à África. A peça tem impacto extraordinário no menino, familiarizado precocemente com as encenações teatrais: é a sua descoberta do Continente africano e do "maravilhoso", diz ele, em mais de uma ocasião.

A referência a Roussel em texto escrito às vésperas da viagem etnográfica pode ser lida como uma homenagem a essa figura decisiva na formação intelectual de Leiris, como atestam as diversas menções feitas a ele ao longo de toda a sua obra, assim como em entrevistas e correspondências. ${ }^{17}$ Ele convive desde cedo com o escritor, que frequenta as soirées musicais organizadas por seu pai, Eugène Leiris, administrador da fortuna do pai de Roussel, oriunda dos negócios comerciais e do patrimônio familiar da esposa. Os dois encontram-se regularmente desde a infância de Michel Leiris, quando este assiste, em sua própria casa, aos concertos de piano e leituras dramáticas de Roussel, tornando-se, a partir de então, seu fiel leitor e admirador (Armel, 1997; Caradec, 1997).

Roussel é, ainda, um dos patrocinadores da Missão Dacar-Djibouti, razão adicional para a homenagem feita ao amigo às vésperas da partida. Em carta datada de 10 de fevereiro de 1931, Leiris reconhece a importância material e simbólica desse apoio:

Acabo de saber por Pierre da magnífica doação que você fez à Missão Dacar-Djibouti [...]. É para mim uma verdadeira e imensa alegria poder associar o seu nome a este empreendimento, que tem aos meus olhos uma significação plena e completa de aventura, não somente científica, mas também poética. Vejo em sua participação nessa obra um símbolo maravilhoso, sinal de aliança do espírito positivo e da imaginação, da etnografia e da poesia [...]. Nada poderia conferir melhor augúrio a essa viagem do que a sua colaboração tão delicada, que vem confirmar de maneira claríssima a ideia que acalento já há algum tempo quanto ao alcance humano e espiritual das pesquisas etnográficas [...]. Como o dizia no domingo - e de acordo com você sobre esse ponto - os 
melhores anos da vida devem se localizar provavelmente entre as idades de seis e onze anos. Se as viagens me atraíram tanto, é que elas me parecem constituir o melhor meio de reencontrar, na idade adulta, essa prodigiosa infância. O apoio material e moral concedido a uma viagem que eu faço, por um autor de tantos livros que me fascinam desde a infância, é para mim um acontecimento, cujo valor pode ser avaliado pelo que acabo de dizer (Leiris, 1998: 290).

Roussel auxilia assim a viabilizar a viagem à África, responsável por uma alteração significativa no percurso de Leiris. Sua presença nesse momento de passagem - que o artigo faz questão de marcar - funciona como um elo entre as duas pontas da vida do etnólogo aprendiz: a infância e a vida adulta; a literatura (a poesia) e a antropologia, associada à possibilidade de alargamento da visão ("seu alcance humano e moral"), mas também à entrada na vida profissional.

Em seu artigo, Leiris resume o núcleo de Impressions d'Afrique, narrativa construída na forma de relato de viagem: ${ }^{18}$ o navio Lyncée naufraga nas costas da África tropical; os náufragos, generosamente acolhidos pelo imperador do país então em guerra contra uma tribo inimiga, e no meio dos quais se encontram membros de uma trupe responsável por fenômenos do gênero Barnum, ${ }^{19}$ se engajam na preparação de uma série de atrações para a grande festa de coroação do soberano, que terá lugar assim que o imperador de Ponukélé anexe o reino rival. No último ato, o soberano, com um manto de gala representando o mapa da África, preside a cerimônia da sagração.

A simplicidade do enredo contrasta com a proliferação de números fantásticos, que ele descreve, e que mesclam grandiloquência plástica e efeitos visuais. Impressions d’Afrique é efetivamente uma "aventura ótica", momento em que Roussel explora ao máximo todo tipo de recurso imagético (Samoyault, 2005: 13). Assim que não parece difícil supor que a descoberta da África pelo menino de 11 anos se dá visualmente: ele vê as fabulações e inventos de Roussel desfilarem diante de seus olhos no palco do Teatro Antoine. E através desse espetáculo aproxima-se, pela primeira vez, do Continente africano, desconhecido na época e, portanto, cercado de clichês e estereótipos. Este é o caso do canibal tornado inofensivo na versão teatral de André Moüezy-Eon, Molikoko, roi nègre, grande sucesso do Teatro do Châtelet, em final de 1929, que Leiris também menciona no artigo, em uma alusão à visão deformada que reina, nesse momento, sobre a África.

Mas a fantasia de Roussel é de outro tipo, indica ele. Um de seus méritos é mostrar o encontro dos europeus e africanos, por meio de imagens projetadas uns sobre os outros: os costumes africanos são vistos (exotizados e inferiorizados) pelo olhar europeu, assim como a visão do progresso e a obsessão técnica dos europeus são apreendidas, de forma grotesca e absurda, pelos africanos. O que é "absolutamente genial nas construções poéticas de Roussel", diz ele, é que elas apresentam "[...] de um lado, uma África, muito pouco parecida àquela que podíamos conceber em nossa imaginação de meninos brancos, e, de outro lado, uma Europa de tantos fenômenos e invenções 'abracadabrantes', que talvez 
se encontre assim figurada no espírito desses que chamamos, com desdém, de primitivos" (Leiris, 1930: 407).

O Roussel que Leiris menciona de modo explícito no primeiro fragmento do seu ensaio é o autor de Impressions d'Afrique. Mas é possível localizar outra presença de Roussel no texto, implicitamente referido, e fundamental para melhor qualificarmos o "olho do etnógrafo" em questão; refiro-me ao autor do poema La vue (1903).

La vue aparece em cinco colunas no Le Gaulois du Dimanche, de 18 e 19 abril 1903. ${ }^{20}$ Trata-se da descrição minuciosa de um balneário praiano a partir da imagem contida na base de um porte-plume avec vue. ${ }^{21} \mathrm{O}$ escritor descreve cuidadosamente a vista: a paisagem natural (rochedos, mar e céu) e personagens (grupos de crianças brincando, casais, pescadores, timoneiros, músicos em um quiosque, banhistas, animais). Descreve também o próprio ato de descrever: fechar o olho esquerdo; colar o direito ao objeto, imobilizado na posição vertical de modo a ver a paisagem; em seguida, inclinar a caneta e registrar o que o olho (um deles) vê.

As operações de ver e descrever, longe de simultâneas, encontram-se separadas por um intervalo de tempo, indica o poema: é preciso suspender uma das atividades de modo que a outra possa se realizar. A minúscula vista, contida no interior do objeto, imobiliza o olho - o esquerdo separado do direito - e a mão, destacando cada uma das atividades, objetificadas nas partes do corpo que as possibilitam. Tudo é objeto, até mesmo os personagens descritos no poema.

Os limites precisos implicados nas ações de ver e descrever - a redução do olhar pelo fechamento de um dos olhos e pelo pequeníssimo orifício da caneta, assim como a interrupção da observação de modo a que a escrita possa ter lugar - não impedem o acesso ao amplo e detalhado panorama que se revela ao poeta e ao leitor do poema: paisagem excessiva pela profusão de planos ("à esquerda", "à direita", "ao fundo", ou "mais ao fundo", diz o narrador) e pela enumeração das coisas que se apresentam ao olhar (Montier, 2007). "Com um olho de menos o observador do porte-plume não cessa de ver coisas a mais" (Lascault, 1977: 39).

O termo vue, em francês, (como "vista" em português) condensa uma série de sentidos. É ato de ver, assim como aquilo que é visto. Define também uma perspectiva, além de ser o órgão da visão, o olho. Não é difícil pensar em La vue como uma outra História do olho, título que dará Bataille à sua novela, alguns anos depois (Lascault, 1977: 36-37). Não é difícil considerar a novela de Bataille, publicada em 1928, como mais uma das menções veladas do texto de Leiris.

Bataille, amigo de Michel Leiris desde 1924, está na origem do seu interesse pela antropologia; é ele quem o introduz nas leituras etnológicas, nas discussões sobre a "psicologia do primitivo" e nos círculos especializados, que incluem, entre outros, Alfred Métraux. Leiris, por sua vez, aproxima o amigo do grupo do ateliê de André Masson - do qual participam Joan Miró, Antonin 
Artaud, Georges Limbour e Armand Salacrou -, em um momento em que parte dele adere ao surrealismo de André Breton. É ainda Bataille que estimula Leiris a começar, em 1925, um tratamento psicanalítico com Adrien Borel, também seu psicanalista. É Borel, por sua vez, quem encoraja Leiris a aceitar o convite feito por Griaule para que participe da Missão Dacar-Djibouti durante dois anos. ${ }^{22}$ A psicanálise está também na raiz da escolha da antropologia como atividade profissional:

Não foi graças à psicanálise que eu escrevi, eu já escrevia antes. Mas foi graças a ela que, voltando da Missão Dacar- Djibouti, tive o bom senso de escolher um diploma em letras e me instalar na profissão de etnólogo. Acho que se não tivesse sido prescrito pelo tratamento, eu teria feito parte da missão de qualquer modo, ainda que Borel, meu psicanalista, tenha me encorajado fortemente a aceitar a proposta de Griaule, que me oferecia tomar parte da viagem transafricana que ele projetava. Acho que no início do tratamento eu estava em tal estado de perturbação que não teria a coragem de obter um certificado universitário na volta da viagem (Leiris, 1992: 52-53). ${ }^{23}$

Ainda que não nomeado, Bataille está presente no artigo escrito por Leiris para Documents (mais uma história do olho?). Desde o título, o autor substitui o caráter impalpável do olhar pela materialidade do órgão-objeto - trata-se do olho do etnógrafo -, retomando com isso a acepção material do termo, que ela possui em Bataille, e um elemento forte do repertório surrealista: o olho pendurado no pêndulo do metrônomo adquirido por Man Ray em 1923 (Indestructible object), ou o olho cortado à navalha, do filme de Luis Buñuel e Salvador Dalí, Le chien andalou (1928). "Olho" é ainda uma das entradas do Dicionário de Documents ( $\mathrm{n}^{\circ}$ 4, 1929), que vem acompanhado de imagens, entre as quais, uma fotografia da atriz Joan Crawford com os olhos arregalados. ${ }^{24}$

$\mathrm{Na}$ seção do verbete assinada por Bataille, Friandise cannibale [Gulodice canibal], ele sublinha as ambiguidades que cercam o órgão, associado à sedução e ao horror; ambiguidades fartamente exploradas na novela, publicada um ano antes: as ambivalências de um órgão que articula alto e baixo, cabeça e ânus. Leiris retoma o ponto no comentário que publica, tempos depois, sobre a novela do amigo, sublinhando a importância do tema do olho para Bataille:

Nessa época, o tema do olho é tão importante para Bataille que o verbete do dicionário consagrado ao termo compreende dois outros textos redigidos por iniciativa sua: um, filológico, de Robert Desnos, comentando, sob o título de "Imagem do olho", algumas expressões correntes em que intervêm ora a palavra, ora a noção de olho, por vezes com um subentendido maroto; o outro, etnográfico, de Marcel Griaule, tratando da crença do mau-olhado, sem contar com uma nota final, assinalando que a locução "faire l'œil", tida por tão familiar, ainda não foi admitida no dicionário da Academia (Leiris, 2003: 111).

Olho, ovo, ânus, sol, tanto na novela como no verbete, Bataille constrói uma série metafórica associando elementos concebidos como opostos, indica Leiris: o terrível e o risível, o resplandecente e o repulsivo, o pesado e o leve, o venturoso e o nefasto. 
O "olho do etnógrafo" se inscreve, portanto, nessa galeria de imagens do olho, no interior da qual seu sentido evidencia-se. De saída, é possível afirmar que o título faz referência ao olho do etnógrafo que ele ainda não é. Assim que o olho, nesse caso, é objeto destacado do sujeito, sobre o qual ele se debruça como tema e matéria; é olho, coisa singular, como em Roussel e em Bataille. Estamos diante do órgão desligado da experiência do sujeito que, se ainda não é etnógrafo, não pode experimentar esse instrumento, descrevendo o que vê com a sua ajuda. Por isso a narrativa é tudo, menos descrição, sendo construída por meio de recuos e avanços no tempo a partir da imaginação e da memória, domínios aos quais é possível ter acesso mesmo de olhos fechados.

\section{SEGUNDO SEGMENTO}

O ensaio se desenrola no ritmo das lembranças e das associações. À recordação da montagem teatral de Impressions d'Afrique, de Roussel, no primeiro segmento, Leiris engata outra: a historieta infantil, The story of little Black Sambo (1899), de Helen Bannerman, ${ }^{25}$ lida perto dos 30 anos, quando ele "já conhecia Griaule e se ocupava da etnografia”. Não se trata, nesse caso, de uma recordação de infância, mas de outra forma de reencontrar sentimento de encantamento similar ao provocado pelas imagens africanas descobertas na infância.

O que diz a história do pequeno africano? (ou do indiano - "pouco importa”, observa Leiris). Era uma vez um menininho negro, Little Black Sambo, para quem a mãe faz um lindo casaquinho vermelho e belas calças azuis. O pai, por sua vez, vai ao bazar e compra-lhe um bonito guarda-chuva verde, e um magnífico par de sapatos cor de púrpura. Metido em todas as roupas novas, o menino sai em um passeio pela floresta. E logo encontra um tigre, que diz: "Black Little Sambo, vou te comer!" E o menino implora: "não faça isso, Sr. Tigre, que lhe dou meu casaco vermelho". E o tigre parte, com o casaco novo, acreditando ser o mais belo tigre da floresta. Um segundo tigre aparece, e a história se repete: "Black Little Sambo, vou te comer!" E o menino escapa dando ao tigre as calças azuis. E a situação se recoloca. Diante de um terceiro tigre, o menino dá os seus sapatos. E a um quarto, oferece o guarda-chuva. Ao final, destituído de todos os seus pertences, Black Little Sambo vai embora chorando. No caminho de casa, porém, escuta um estrondoso barulho. Escondido atrás de uma árvore, vê os tigres brigando, cada qual querendo ser o mais belo e grandioso. Tão furiosos estão eles que arrancam todas as roupas e começam a se devorar, uns aos outros. Aproveitando o momento, Black Little Sambo recupera os pertencentes abandonados pelos tigres, que não param de lutar, em movimentos cada vez mais rápidos e enérgicos, até que se fundem, dando origem a uma enorme poça de manteiga derretida, que resta depositada ao pé de uma árvore. Nesse instante, o pai do menino volta do trabalho com um grande recipiente de cobre nos braços 
e, ao ver a poça de manteiga, exclama: "que deliciosa manteiga derretida; vou levá-la para casa de modo que minha mulher a utilize na cozinha”. E assim foi. Em casa, a mulher faz deliciosos crepes com a manteiga para o jantar. Todos comem muito: a mãe, 27, o pai, 55, e o pequeno Little Black Sambo, 169, pois estava com muita fome!

A história, ancorada em uma inversão - o pequeno, ameaçado e roubado, devora com grande apetite seus agressores, em um repasto canibal - se associa a cenas de Roussel e a outras imagens dos negros africanos em circulação naquele momento (a de Malikoko, roi nègre, por exemplo), permitindo que Leiris introduza diretamente, no final do ensaio, o tema da viagem etnográfica, que o subtítulo anunciara. A viagem, prestes a acontecer, permitirá, espera ele, superar as visões equivocadas, construídas pelas "lentes deformadoras" da cultura europeia. Deve "contribuir para dissipar esses erros", vendo os reais contornos do mundo e dos homens, tirando véus e afastando fantasmagorias.

Nesse último segmento do texto um sentido suplementar se associa ao "olho do etnógrafo", relacionado agora a uma nova visão e consciência, diretamente ligada à ideia de antropologia como empresa de alcance humanista, como dissera um pouco antes: "[...] ciência a mais humana porque não limitada - como a maior parte das outras - aos homens brancos, a sua mentalidade, interesses, técnicas [...]" (Leiris, 1930: 407). E, nesse momento, Leiris convida os amigos, literatos e artistas - "boa parte deles absorvidos em querelas estéticas estéreis, no interior de pequenos grupos" - a fazerem o que ele fará: viajar como etnógrafo, e não mais como turista, "viajante sem coração, sem olhos, sem ouvidos" (Leiris, 1930: 413).

Segundo Leiris, o olho do etnógrafo está preparado para ver (e conhecer) porque se associa aos demais sentidos e sentimentos. Despindo-se de suas "maneiras de branco", o etnógrafo logra se aproximar de Arbanakat, o herói do conto africano, com o qual ele encerra o texto, e que, diante do outro, se pergunta: afinal, quem sou eu?

Assim que o exercício reflexivo, e autorreflexivo, que a viagem etnográfica permite, é experimentado antes mesmo de sua realização, com a ajuda da literatura e do trabalho em Documents, laboratório no qual Leiris prepara-se para viajar, ver e descrever. As leituras antropológicas, os cursos de Mauss e, sobretudo, as artes fornecem os ensinamentos primeiros, despertando o interesse pelos outros povos e culturas: "cheguei à antropologia pela arte negra", afirma em nota (Leiris, 1930: 414).

As artes funcionam como acesso à antropologia para Leiris e para outros de seus contemporâneos, Bataille, Schaeffner e Métraux. Este último, que ao contrário dos demais, desenha um percurso estritamente antropológico, enfatiza como seus companheiros de geração, o impacto que o ambiente artístico francês dos anos 1920, sobretudo o surrealismo, representa em sua descoberta da antropologia. Diz ele, sobre o seu período de formação, entre os anos 1924 e 1926: 
Penso neles ainda com verdadeira emoção; era um período de ebulição e rebelião e todos nós nos sentimos abalados. Em uma palavra: o surrealismo começava, momento em que era mais vigoroso. Eu não fazia parte do movimento, mas conheci vários surrealistas, fui amigo de Georges Bataille, em suma, acompanhei essa corrente, à qual a etnografia aportou elementos extremamente preciosos. Subitamente os povos exóticos vinham confirmar, de algum modo, a existência de aspirações que não podiam se exprimir em nossa própria civilização. A primeira manifestação desse sentimento foi despertada pelo interesse pelas artes exóticas, primeiro africanas, em seguida as da América pré-colombiana. Muito cedo, porém, o interesse puramente estético foi ultrapassado pela surpresa diante do que havia de incongruente e extraordinário nas civilizações exóticas (Métraux, 1964: 21).

O primitivismo artístico desperta vocações, como as de Leiris e Métraux, ainda que tenha representado também limites ao conhecimento dos outros povos, reconhece Métraux: "Nessa atitude entrava, porém, tanto ingenuidade quanto preconceitos; pedia-se è etnografia o pitoresco, o bizarro; somente mais tarde, esta exaltação, este entusiasmo foram canalizados em prol da ciência" (Métraux, 1964: 21).

Munido de sentimento semelhante - e ansioso por romper com as "querelas estéticas estéreis" - Leiris viaja para ver com "olhos" de etnógrafo (e o plural empregado no final do texto enfatiza o sentido de perspectiva). Mas, uma vez realizada, a viagem recoloca outras fantasmagorias, indica o diário escrito ao longo da Missão Dacar-Djibouti, A África fantasma: "Em 1933, retornei tendo destruído pelo menos um mito: o da viagem enquanto meio de evasão" (Leiris, 2003: 186).

O relato posterior da viagem constitui, então, o esboço sombrio - ele mesmo fantasmagórico - da experiência dilacerada da viagem etnográfica, jogando por terra expectativas alimentadas antes dela. Nesse sentido, o diário toma a forma de uma etnografia daquele que viaja, transformando-se em exercício de autodescoberta, de encontro consigo mesmo; "eu", vale lembrar, modificado pelo encontro com o "outro" de carne e osso, o que provoca no pesquisador enorme estranhamento: quem sou eu, pergunta-se ele, mais uma vez, como Abarkanat no final do conto africano mencionado em 1930, às vésperas da partida.

À estreita articulação entre viagem e autobiografia que A África fantasma evidencia soma-se o esforço de produção de uma escrita de si que almeja subverter a marcha do tempo, projeto reiterado em L'âge d'homme (1939). Neste autorretrato, esboçado entre seus 29 e 34 anos, o tempo, plasticamente representado por imagens de diversas ordens, é antítese de qualquer tipo de história. E as imagens que se sucedem na narrativa falam da experiência do envelhecimento, do aprendizado do corpo, de uma pedagogia do amor e da morte. Escrever para banir o tempo, controlar o futuro e, no limite, vencer a morte. ${ }^{26}$

A viagem aparece como recurso adicional para lidar com o mesmo propósito, em função da articulação que engendra entre marcha do tempo e progressão no espaço, indica o relato da viagem à África. “O olho do etnógrafo" é 
tradução fiel, e precoce, desse procedimento, antecipando um tópico central da obra do autor. Em suas palavras: "Quanto a mim, vejo a viagem - além de melhor método para adquirir um conhecimento real, quer dizer, vivo - sobretudo como a realização de certos sonhos de infância, ao mesmo tempo que um meio de lutar contra a velhice e contra a morte, me jogando no espaço para escapar imaginariamente à marcha do tempo [...]" (Leiris, 1930: 413).

Artigo recebido para publicação em julho de 2011.

Fernanda Arêas Peixoto é doutora em Antropologia Social, professora do Departamento de Antropologia da Universidade de São Paulo (USP) e pesquisadora do Conselho Nacional de Desenvolvimento Científico e Tecnológico (CNPq). Autora de Diálogos brasileiros: uma análise da obra de Roger Bastide (2000) e organizadora de, entre outros, Gilberto Freyre em quatro tempos (2003), Antropologias, histórias, experiências (2004) e A cidade e seus agentes: práticas e representações (2006). 


\section{NOTAS}

1 Uma versão preliminar deste texto foi apresentada na forma de comunicação oral no seminário Saberes Surrealistas, realizando no Instituto de Filosofia e Ciências Sociais da Universidade Federal do Rio de Janeiro (IFCS/UFRJ), nos dias 10 e 11 de setembro de 2007. Emerson Giumbelli, parceiro na organização do seminário, está na origem dessa reflexão. Dividi parte dessas notas, um pouco depois, com o grupo do Núcleo de Antropologia da Performance e do Drama (Napedra/USP), coordenado por John C. Dawsey, a quem deixo registrado o meu agradecimento pelo interesse e sugestões. O artigo é parte do Proyecto de Investigación Inscripciones literarias de la ciencia: ámbitos interdiscursivos, transferencias conceptuales y procesos semióticos (ILICIA). Junta de Castilla y León, Ref. SA021A11-1, Universidade de Salamanca.

2 A brochura Titres et travaux de Michel Leiris constitui a parte central de seu dossiê de candidatura ao posto de diretor de pesquisa do Centre National de la Recherche Scientifique (CNRS), apresentado em setembro de 1967. Publicado originalmente na revista Gradhiva, 9, 1991, é reeditado em C'est-à-dire (1992), ao lado de entrevista concedida pelo autor a Sally Price e Jean Jamin.

3 Michel Leiris participa do movimento surrealista de 1924 a 1929. Datam, dessa época, um volume de poesias, Simulacre (com litografias de André Masson, 1925) e outro de prosa, Le point cardinal (1927), ambos republicados em Mots sans mémoire (1969). No mesmo período, concebe La grande fuite de neige, uma primeira aproximação do universo das corridas espanholas, que tanto o fascinam (publicado pela primeira vez em 1934), Glossaire j'y serre mes gloses, espécie de dicionário poético publicado na Révolution surrealiste (1925/26) e uma série de relatos de sonhos, editados na mesma revista, cuja compilação aparece em 1945, com o título Nuits sans nuit.

4 Financiada por Georges Wildenstein, galerista e editor de La Gazette des Beaux-Arts, e concebida inicialmente como uma revista de arte, o primeiro número de Documents vem à luz em 15 de abril 1929 anunciando os seus propósitos já nos subtítulos: primeiro, "Doutrinas, Arqueologia, Belas-Artes, 
Etnografia" e a partir do $\mathrm{n}^{\circ} 4$ de 1929: "Arqueologia, BelasArtes, Etnografia, Variedades". No total são 15 números, editados em dois anos, 1929 e 1930. Além de Bataille, a revista teve entre seus principais animadores, Georges-Henri Rivière e Carl Einstein (1885-1940), poeta alemão e especialista em arte ocidental moderna. Seus colaboradores vinham das mais diferentes áreas e filiações estéticas, “mistura impossível”, nos termos de Leiris (1996: 260).

5 Marcel Griaule (1898-1956) assume o cargo de secretário de redação de Documents (função a ele reservada por Georges-Henri Rivière) no momento em que regressa de uma expedição na Etiópia, em 1929. No final desse mesmo ano, começa a esboçar o projeto da Dacar-Djibouti, apoiado por Paul Rivet (1886-1958) e pelo próprio Rivière, e com sustentação institucional do Muséum National d'Histoire Naturelle [Museu Nacional de História Natural] (onde Rivet ocupará a cátedra de antropologia, em 1928) e do Institut d'Ethnologie [Instituto de Etnologia] da Universidade de Paris.

6 Sobre a presença da etnografia na revista, ver, ainda, Maubon (1999).

7 Todas as traduções dos trechos em francês, que acompanham este artigo, são de minha autoria.

8 Etnólogo e musicólogo francês, André Schaeffner (18951980), é responsável pelo setor de etnomusicologia no Musée d'Ethnographie du Trocadéro a partir de 1929, onde ele criará um Departamento de Organologia e uma sala de instrumentos musicais. Quando retorna da Missão Dacar-Djibouti, em 1932, organiza a fonoteca do museu.

9 Ver, entre vários outros, Jamin (1984; 1996), Nélia Dias (1991), D. Hollier (1991) Clifford (1981), Brumana (2005).

10 Leiris compõe um retrato de Rivière em Rapace à l'œil bleu..., editado primeiro em L'Homme, XXV/4, 1985, e depois em Zébrage (Leiris, 1992a).

11 L'Amérique disparue foi originalmente publicado em Les Cahiers de la République, des Sciences et des Arts, XI, 1928.

12 Sobre a exposição e seu lugar como embrião de Documents, ver Leiris (1992: 32 e 1992b: 857, nota 50) e Armel (1997: 266). Alliete Armel afirma ter sido Bataille quem apresentou Rivière a Métraux, ao contrário das indicações de Leiris. 
13 Leiris descreve a sua primeira ida ao ateliê de Masson no número 45 da rua Blomet como uma "verdadeira viagem iniciática", que irá introduzi-lo no "estado de espírito" particular que ali reinava (1992a: 221-223).

14 Não por acaso, o primeiro número da publicação traz um texto assinado por Rivière sobre o Musée d'Ethnographie du Trocadéro, onde ele faz um balanço da situação do museu e apresenta os planos de reforma e remodelação das coleções.

15 Hugo Adolf Bernatzik (1897-1953) é antropólogo e fotógrafo austríaco.

16 Habbé é a palavra peul para "infiel”, empregada para designar os dogon até Griaule.

17 O débito de Leiris em relação a Roussel, regularmente reafirmado, se manifesta ainda em seu empenho em editar, em 1935, Comment j'ai écrit certains de mes liures, livro dedicado aos procedimentos da criação literária de Roussel. Leiris acalentou ainda o projeto de escrever a biografia do autor após a sua morte. Se o projeto não se concretizou, o Cahier Raymond Roussel mostra o acompanhamento detido que fez da vida e obra do escritor (Leiris, 1998).

18 Observe-se que Roussel faz questão de indicar que embora tenha viajado muito, "de todas essas viagens, nada retirou para os seus livros” (apud Leiris, 1992a: 42).

19 Os espetáculos circenses de Phineas Taylor Barnum (18101891) fizeram época em função dos recursos cênicos empregados, e dos fenômenos, figuras e animais raros exibidos.

20 Le Gaulois du Dimanche é o suplemento literário semanal de Le Gaulois, jornal que será depois incorporado por Le Figaro. Tendo circulado de junho de 1897 a agosto de 1914, o suplemento publicava regularmente uma série de folhetins. La vue é reeditado em livro, em 1904 (edições Lamerre) e em 1963 (edições J.-J. Pauvert).

21 Longas canetas a pena, típicas da belle-époque, esculpidas em marfim ou madeira, em cujo topo, achatado, podia-se pintar pequenas paisagens ou figuras.

22 Sobre as relações entre Bataille e Leiris, ver Échanges et correspondances (2004).

23 O tratamento psicanalítico, iniciado por indicação do amigo Bataille, é responsável pela proeminência que o tom au- 
tobiográfico vai assumir nos escritos de Leiris. Da mesma forma que Bataille escreve A história do olho sob o impacto do tratamento com Borel - iniciando com esse livro sua atividade literária -, Leiris escreve sua autobiografia, A idade viril (não por acaso, dedicada a Bataille) sob os efeitos do tratamento psicanalítico. Nos dois casos, um projeto autobiográfico toma forma como parte de um processo de cura.

24 A ilustração, sugere Didi-Huberman, teria sido ideia de Leiris, que em seu diário, no dia 11 de maio de 1929, confessa sua predileção por esse retrato da atriz (apud Didi-Huberman, 2003: 77, nota 2).

25 Escritora escocesa, Helen Bannerman (1862-1946) é autora de várias histórias infantis, sendo Black Littlle Sambo a mais célebre delas, e também uma das mais controvertidas, em função da visão caricatural do pequeno indiano (ou da criança tâmil) projetada pelo texto e por suas ilustrações originais. A história teria contribuído para fazer de "sambo" uma designação pejorativa.

26 Trabalhei mais detidamente o ponto na apresentação à edição brasileira de A África fantasma, "A viagem como vocação: antropologia e literatura na obra de Michel Leiris" (2007). 


\section{REFERÊNCIAS BIBLIOGRÁFICAS}

Armel, Arliette. Michel Leiris. Paris: Fayard, 1997.

Bataille, Georges. L'Amérique disparue. In: . Euures Complètes. Paris: Gallimard, [1928] 1970, pp. 152-158 (vol. 1). . História do olho. São Paulo: Cosac Naify, [1928] 2003. \& Leiris, Michel. Échanges et correspondances. Paris: Gallimard, 2004.

Brumana, Fernando G. Soñando con los Dogon: en los orígenes de la etnografía francesa. Madri: Consejo Superior de Investigaciones Científicas, 2005.

Caradec, François. Raymond Roussel. Paris: Fayard, 1997.

Clifford, James. Sobre o surrealismo etnográfico. In: Gonçalves, José Reginaldo (org). A experiência etnográfica: antropologia e literatura no século XX. Rio de Janeiro: Ed. UFRJ, [1981] 1998.

Dias, Nélia. Le musée d'ethographie du Trocadéro (1878-1908): anthropologie et muséologie en France. Paris: Éditions du CNRS, 1991.

Didi-Huberman, Georges. La ressemblance informe ou le gai savoir visuel selon Georges Bataille. Paris: Macula, 2003.

Documents. Edição fac-similar. Paris: Jean Michel Place, 1991 (2 vol.).

Hollier, Denis. La valeur d'usage de l'impossible. Documents. Edição fac-similar. Paris: Jean Michel Place, 1991 (2 vol.).

Jamin, Jean. Aux origines du Musée de L'Homme: la mission ethnographique et linguistique Dakar-Djibouti. Cahiers ethologiques. La mission ethnographique Dakar-Djibouti, 1931-1933, 1984, 5, Presses Universitaires de Bordeaux, nouvelle série.

. De l'humaine condition de "Minotaure". In: Gaume, Claude (org.). Régards sur Minotaure, la revue à tête de bête. Genebra: Musée d'Art et d'Histoire, 1987, p. 78-87.

. Introduction à Miroir de l'Afrique. In: Leiris, Michel. Miroir de l'Afrique. Paris: Gallimard, 1996, p. 9-59.

. Documents revue: la part maudite de l'ethnographie. L'Homme, 1999, 151, p. 257-266.

Lascault, Gilbert. Sept petites vues sur La vue. L'Arc, 1977, 68 , p. $35-40$. 
Leiris, Michel. L'œil de l'ethnographe. Documents, 1930, 7, p. 404-414.

. A África fantasma. São Paulo: Cosac Naify, [1933] 2007.

. A idade viril: precedido por Da literatura como tauromaquia.

São Paulo: Cosac Naify, [1939] 2003.

. Nos tempos de Lord Auch. In: Bataille, Georges. História do olho. São Paulo: Cosac Naify, [1971] 2003, p.105-128.

. C'est à dire: entretien avec Sally Price et Jean Jamin suivi de

Titres et travaux. Paris: Jean-Michel Place, 1992.

. Zébrage. Paris: Gallimard, 1992a.

. Journal, 1922-1989. Paris: Gallimard, 1992b.

. De Bataille l'impossible à l'impossible. Documents. In: . Brisées. Paris: Mercure de France, 1996.

. Roussel \& Co. Paris: Fata Morgana/Fayard, 1998.

Métraux, Alfred. Entretiens avec Alfred Métraux. L’Homme, 1964, IV/2, p. 20-32.

Montier, Jean-Pierre. Et vint La vue de Raymond Roussel. Disponível em <http://pierre.campion2.free.fr/montier_roussel. htm>. Acesso em 28 jun. 2011.

Maubon, Catherine. Documents: la part de l'ethnographie. Les Temps Moderne, 1998/1999, 602, p. 48-65.

Roussel, Raymond. La vue, 1903. Disponível em <gallica.bnf. fr/ark:12148/bpt6k108427z>. Acesso em 28 jun. 2011.

Samoyault, Tiphaine. Présentation: impressions d'imaginaires. In: Roussel, Raymond. Impressions d'Afrique. Paris: Flammarion, 2005, p. 7-24.

Yvert, Louis. Bibliographie des écrits de Michel Leiris, 1924-1995.

Paris: Jean Michel Place, 1996. 


\section{Palavras-chave: Resumo:}

Michel Leris; O artigo propõe uma leitura do texto do escritor e antroViagem e etnografia; pólogo Michel Leiris (1901-1990), "L'œil de l'ethnographe Documents; Viagem e (à propos de la Mission Ethnographique Dakar-Djibouti)", autobiografia; publicado na revista Documents $(1930,7)$, e escrito pouco L'œil de l'ethnographe. antes de sua primeira viagem de campo à África, quando ele integra a Missão Etnográfica e Linguística Dacar-Djibouti (1931-1933). Trata-se de exercitar um olhar aproximado sobre esse relato de viagem (ou sobre a viagem) antes de sua realização, pensando os seus rendimentos para uma reflexão sobre a viagem etnográfica, sobre o papel de Leiris na redação de Documents, na Paris do entre-guerras e sobre sua obra.

\section{Keywords: Abstract:}

Michel Leiris; The paper proposes a reading of "L'oeil de l'ethnographe Journey and Ethnography; (à propos de la Mission ethnographique Dakar-Djibouti)", Documents; Journey and published in the journal Documents $(1930,7)$ and written by autobiography; the anthropologist Michel Leiris (1901-1990) shortly before L'oeil de l'ethnographe. his first research expedition to Africa, when he joined the Ethnographic and Linguistic Mission Dacar-Djibouti (19311933). It looks at this journey report before the journey happened, examining its benefits for a reflection on the ethnographic journey, on Leiris' role as one of the editors of Documents in Paris between the wars, and on his work. 